1984

\title{
State Aid and City Needs: An Examination of Residual State Aid to Large Cities
}

John P. Pelissero

Loyola UniversityChicago, jpeliss@luc.edu

\section{Recommended Citation}

Pelissero, John P., "State Aid and City Needs: An Examination of Residual State Aid to Large Cities," Journal of Politics 46 (August 1984): 916-935.

This Article is brought to you for free and open access by the Faculty Publications at Loyola eCommons. It has been accepted for inclusion in Political Science: Faculty Publications and Other Works by an authorized administrator of Loyola eCommons. For more information, please contact ecommons@luc.edu.

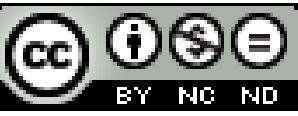

This work is licensed under a Creative Commons Attribution-Noncommercial-No Derivative Works 3.0 License. 


\title{
State Aid and City Needs: \\ An Examination of Residual State Aid to Large Cities
}

\author{
John P. Pelissero \\ Texas A \& M University
}

Dye and Hurley's (1978) conclusion that the states are somewhat more responsive to city needs than the federal government was questioned on methodological grounds by Ward (1981). The point of contention was Dye and Hurley's use of per capita measures of state/federal aid and urban needs. The research reported here examines state aid to the fortyseven largest U.S. cities, and employs residual measures of state aid allocations before and during the urban crisis. Multiple regression of residual state aid on social, economic, or fiscal need indicators shows the states to have been very responsive to city needs over time, and lends substantial support to the findings of Dye and Hurley.

\section{S}

ince the early 1960s cities have encountered a variety of persistent problems that remain beyond their own means to resolve. A common understanding among policymakers in the federal system is that large cities have been unable to provide a smorgasbord of public services and to cope with a variety of city problems without assistance from the federal and state governments. In the late 1960s the "urban crisis" was recognized and addressed by a host of federal programs. But that situation has not gone away. Today the crisis in the cities does not pervade the media - it has been replaced by more urgent national and international concerns. But the distress of the 1960s and 1970s is very much present in large central cities of the 1980s.

The Reagan administration no longer wants the cities to look to the

* This is a revised version of a paper presented at the Annual Meeting of the Midwest Political Science Association, 20-23 April 1983, in Chicago. I would like to thank David R. Morgan for suggesting that I study this policy area and for his assistance and encouragement throughout the project. I also want to acknowledge the helpful criticisms and suggestions of Michael Gant, F. Ted Hebert, Keith Hamm, Kenneth Meier, Charles Wiggins, and two anonymous reviewers. 
federal government as the "court-of-first-resort" to help resolve their problems. This process of direct problem solving through federal fiscal assistance may have been necessary in the 1960s, but the current administration wishes it to be replaced by other means. The "new" New Federalism initiatives that the administration advanced in 1981 included a large turnback of federal grant programs to the states. Along with some federal dollars to help the states throughout most of this decade, the Feds now want the states to become the courts-of-first-resort for the resolution of city problems. Among many criticisms of Reagan's New Federalism plans, the issue of the states' capacities to respond to urban problems has been raised by skeptics. And many city government officials fear that the states will not be willing to accept the challenges of this responsibility. Both concerns have their basis in historical fact: states were often the least-prepared level of government to engage in any urban problem solving. This paper looks at city problems and the ways that states have responded to them during the past two decades.

A useful dichotomy of the myriad of problems perpetuating the crisis in the cities is that offered by Tobin $(1979$, p. 10). One set of problems is local in origin: mismanagement of city governments, inefficiency of municipal operations, and outmoded political structures. These are "problems of the city," and they may be remedied by the city in many instances. The second set of problems is really a mirror of national problems that are "centered in the city," such as poverty, crime, and substandard housing. These latter problems are shaped as much by national forces as by local conditions. Thus, they frequently are regarded as requiring the assistance of higher-level governments, federal or state, to achieve any resolution.

\section{Intergovernmental Responses to City Problems}

How have the federal and state governments responded to this need for assistance? Until recently not much empirical research had been applied to this question. However, in the late 1970s, studies of federal and state aid targeting to needy cities became more common. Much of this research has concentrated on the federal government's response to urban problems. Saltzstein (1977) did a limited comparison of Texas cities' federal aid receipts. He found virtually no relationship between federal aid and common measures of local social and economic conditions.

The Saltzstein single-state study was followed by three more broadly based cross-sectional research efforts which obtained much different results. One, focusing on the needs of major U.S. cities in relationship to federal aid allocations, was that of Cuciti (1978). This study, conducted for the U.S. House of Representative's Committee on Banking, Finance, 
and Urban Affairs, examined the social, economic, and fiscal needs in forty-five large cities. Five different programs of federal aid were found to be related to at least one dimension of need in these cities. Contrary to this finding, Dye and Hurley (1978) showed that per capita federal spending (both in total and by selected program) was only weakly related to common measures of city need. Additionally, they found that federal grants were somewhat less responsive to need than state grant programs. Stein (1981a) also examined the relationship between per capita federal aid and city needs. Like Cuciti, he found federal aid to be related to current need, as well as responsive to changes in city need, fiscal capacity, or both (p. 338).

This growing body of literature on federal aid allocations is being met by an enlarging set of studies on state aid targeting. ${ }^{1}$ Dye and Hurley (1978, pp. 203-6) looked at state grants and found them to be somewhat more responsive to city needs than federal grants. However, their findings have been challenged by Ward (1981) on both methodological and theoretical grounds. Ward has objected to Dye and Hurley's use of per capita measures of aid. Arguing that total measures of state and federal aid do bear strong relationships to the size (rather than proportion) of the population in need (p. 87), Ward contends that these authors' conclusions are invalid. Ward raises important methodological questions which are discussed in more detail later in this paper.

A study by the National Governors' Association (NGA; 1979) looked at both federal and state aid to distressed cities. Emphasizing the importance of funneling all federal aid for cities through the states, the report analyzed the impact of federal and state aid upon four indicators of city hardship, as explored in previous studies (Nathan and Adams, 1976; Cuciti, 1978). The NGA study concluded that responsiveness to city problems is best met by a combination of federal and state aid. From a somewhat self-serving perspective, it urged the federal government not to bypass the states when attempting to assist distressed cities. Because the states are closer to the needy communities, the governors' report suggested, the states could assemble a better aid package for cities with the help of federal monies. In general, the NGA study lends support to the findings of Dye and Hurley.

Further support for these findings appears in two related analyses of state aid to cities by Stein $(1981 \mathrm{~b}, 1982)$. Focusing on per capita state aid to cities in relation to multiple indicators of social and fiscal need, Stein found state aid (in a pooled sample of cities) was responsive to measures of need. However, an important caveat was that this finding did not hold

${ }^{1}$ For example, see the special issue of The Urban Interest 3 (1981) on "Targeting State and Federal Resources to Urban Areas," edited by Vincent L. Marando and UIf Zimmerman. 
true across all states. Emphasizing that there are fifty separate and distinct state aid systems, Stein subsequently analyzed the targeting of aid in each of the states and concluded that only a handful of states were actually good targeters of aid. As a result, Stein noted that the findings of such studies as Dye and Hurley and NGA were misleading. The overall positive responsiveness to need was likely to have resulted from the actions of those few states which are "consistent targeters" of their needier cities (Stein, 1981b, pp. 53-55).

\section{Measuring State Aid .}

Studies of state aid have shared one commonality - most of the data on state aid allocations have been in per capita form. Dye and Hurley, NGA, and Stein all relied upon per capita measures of aid in their analyses. Ward (1981) raised important questions about using per capita figures in such research, and he drew upon issues raised by Uslaner (1976) to make his arguments. Yet, if one relies upon total measures of state aid and the total level of need (rather than percentage in need), one runs the risk of confirming the obvious. That is, total state aid (state spending) is strongly related to the size of the city's population. An alternative method to measuring state aid is explained below.

Uslaner's (1976) critique of per capita measures in regression analysis demands that researchers consider the theoretical relevance of per capita dependent and independent variables before employing them. His concern rests upon the ideas advanced by Cortes and Przeworski (1971) which suggest that the theoretically meaningful variables (in such areas as state expenditure analysis) are the total figure - not per capita transformations. As Uslaner notes, "State legislators generally deal in absolute dollar and cent terms when deciding the level of state expenditures. There is no evidence that the expenditures of other states serve as a baseline for any individual state" (1976, p. 131). The only theoretically justified use of per capita transformations, according to Uslaner, is in comparing cases on indicators such as relative deprivation, or when one has information that the per capita measures were used in the policymaking process.

Uslaner's argument and his empirical results raise important questions for those who study state and urban policy. If per capita measures are inappropriate, "nonlinear transformations of the original data" (Uslaner, 1976, p. 126), then the more common alternative would be to employ the total figures. This is suggested by Ward (1981) in his examination of Dye and Hurley's (1978) measurement of state and federal responses to urban needs. Ward shows that per capita measures may distort policy analysis by indicating that there is a negative or weak association between per capita federal aid outlays and percent needy when the correlation be- 
tween total outlay and number in need is actually quite strong and positive (pp. 85-87). He does note that the latter finding is somewhat expected since many commonly employed need measures (e.g., elderly, poor population) are also strongly correlated with city population.

Thus we return to the very concern that lead Dye and Hurley as well as other policy researchers to use per capita measures in studying responsiveness to need. That is, one finds that larger cities receive more state/federal aid because they are larger. An alternative approach is to concentrate the policy analysis on that portion of state aid not determined by the population of the receiving jurisdiction. As explained below, this method should satisfy the concerns of both Uslaner and Ward while avoiding the pitfalls of confirming the obvious relationship between size of city and size of outlay. By regressing total state aid figures on city population one can produce residuals that are both useful measures of state aid and improvements over per capita transformations.

In a practical sense, the confounding effects of population should be removed from the state aid measure. This assumes that state aid $=f$ (population) + error. Recognizing this, previous policy analyses have controlled for population differences by employing per capita measures. But through the method suggested here, the population effects are removed in a linear fashion and residual state aid measures that are independent of population are produced (Wonnacott and Wonnacott, 1970, pp. 38-39). The residuals represent that portion of state aid money allocated on bases other than the size of the receiving city. Most decisions about public revenues are political decisions. Thus, the residual portion may include political considerations, as well as city needs or other factors important to state legislators.

Residual measures, it can be argued, are better than per capita measures for several reasons. First, while per capita measures are produced by nonlinear transformations, residual measures are derived from a linear transformation that makes them well suited for use in subsequent analyses with the general linear model. ${ }^{2}$ Second, residuals are considered to be independent of the predictor used to produce them. That is, the general linear model assumes that residuals will be uncorrelated with population and, therefore, independent of this predictor (Kmenta, 1971, pp. 201-5; Wonnacott and Wonnacott, 1970, pp. 152-53). One can test empirically for independence by calculating the zero-order correlation between population and residuals. Independence can be demonstrated if

${ }^{2}$ Uslaner (1976) has adequately discussed and criticized the nonlinear transformations that yield per capita measures. Residuals are appropriate to use in the general linear model because they should meet the basic assumptions of the regression model (Kmenta, 1971, p. 202), particularly those of normality, zero means, and independence. 
this correlation equals (or nearly equals) 0 (see the research design section below).

Third, residual measures allow the policy researcher to concentrate on the discretionary portion of state aid allocations and to draw conclusions from this analysis about the importance of needs, politics, and other factors. There is less certainty, when employing per capita measures, that only the nonpopulation-determined portion of an outlay is being examined.

Finally, residual analysis allows the calculation of residual independent variables as well as dependent (state aid) variables. In this policy area, the independent variables used as predictors of state aid are indicators of city need or distress. Producing residual need measures is important in state aid analyses since many indicators of city need used as predictors of state aid are also strongly correlated with population (Ward, 1981).

In sum, the employment of a residual measure offers significant advantages to policy researchers which are not present in the use of per capita transformations. A more theoretically relevant measure is produced which should allow for a more accurate assessment of state aid policies.

\section{Explaining Ssate Aid Outputs}

Several explanations for the distribution of this residual state aid seem plausible. For example, we might consider the very factors that have been empirically linked with state spending. The capacity of the state fiscal system might explain the residual allocation to cities. States with stronger revenue capacities may be in a better position to send additional money to cities beyond that which might correspond to a city's fair share in terms of population. Despite the current revenue constraints confronting many states due to national or regional economic conditions, the states have improved their revenue capacities in recent years to respond to communities that have more distress than others (see the Advisory Commission on Intergovernmental Relations, 1981a, pp. 33-35; 1981b; 1981c; Lawson and Stenberg, 1982; and Cohen, 1982).

A second possible explanation involves the legal/structural relationship between a state and its cities (Morgan and England, forthcoming). States with more decentralized arrangements for the provision of services may be expected to give more money to cities than states of a highly centralized structure. Support for this hypothesis is found in the research of Stephens and Olson (1979; also, Stephens, 1974). Although they examine state and local rather than state and city financial relationships, their finding that centralized states tend to "give less money to their local entities than those with decentralized arrangements" (1979, p. 59) has application to cities as well.

Several state political factors may also be considered as potential 
stimuli of residual state aid. State-level forces behind the political explanation may include interparty competition (Cnudde and McCrone, 1969; Sharkansky and Hofferbert, 1969; Carmines, 1974; and Tompkins, 1975), legislative professionalism (Grumm, 1971; Carmines, 1974), or the policy innovativeness of the state (Walker, 1969; Gray, 1973; and Savage, 1978). Another important political factor may be the degree of urbanrural conflict in the legislature. States with strong urban interests in the legislature may be expected to produce more prourban legislation, including intergovernmental aid for cities. Other state-level explanations are the socioeconomic characteristics of states - such as size, metropolitan population size, rate of growth, or regional location.

A final consideration may be the level of need in a community. When all other factors are ruled out, it seems entirely plausible that city distress ought to be the most relevant variable in state aid allocations. The focus of this research is on the degree to which the level of need in communities is determinant of residual state aid receipts.

\section{Sample Considerations}

One feature that is not common among the studies of state aid is sample size. Dye and Hurley looked at 243 central cities of Standard Metropolitan Statistical Areas (SMSA). The NGA report was based upon data from fifty-nine selected central cities, while Stein analyzed 845 cities with populations of 25,000 and above. There appears to be some basis for focusing a study of city need or distress on a sample of large cities. For example, Netzer (1970) suggested that the concentration of poverty and racial problems, physical deterioration, and imbalances between service demands and tax resources were most severe in the largest central cities (populations of 500,000 or more) in the U.S. While tax bases were deteriorating in large cities, especially in the Northeast and Midwest, spending (per capita) increased by a faster rate in the twenty-eight largest cities than in all local governments from 1962 to 1972 (Peterson, 1976, p. 41). Between one-quarter and one-third of the poor in the U.S. resided in the nation's central cities from 1959 into the 1970s (Gorham and Glazer, 1976, p. 21)-a proportion that grew larger in later years.

In addition, several studies of city problems have substantiated the acute distress in the largest U.S. cities. Nathan and Adams (1976) found significant problems in more than half of the fifty-five largest central cities studied. Analyses of fiscal problems in large city samples of forty (Schmid et al., 1975) and thirty (Dearborn, 1977) communities each disclosed serious fiscal needs among large municipalities. Bunce (1976) examined needs in cities of different sizes and confirmed that greater need for community development-related policies existed in the largest north- 
eastern, midwestern, and southern cities. Finally, Cuciti's (1978) research for the U.S. House of Representatives was focused on forty-five of the largest cities. She found "above average" problems on different dimensions related to social, fiscal, or economic need in most of the cities. The weight of this empirical research suggests that major problems associated with the urban crisis were quite serious in the largest U.S. cities.

Further, one could argue that the states should be more aware of problems in their larger cities. Teitelbaum, Arnold, and Lyttle (1981) suggest that key state officials might be "more cognizant of the needs of their larger cities." Such an assertion can be supported by the types of information available to state officials about cities. Most of the media centers are located in the states' largest cities - focusing on both national and metropolitan news. Governors have begun to establish liaison or "regional" offices in large cities. Metropolitan representatives now dominate many state legislatures. Finally, state departments of community affairs, advisory commissions on intergovernmental relations, and other state-local bodies provide current information on urban needs - including major city needs - to state officials (Advisory Commission, 1981c). Together, these information sources keep governors, legislatures, and agencies aware of major city problems.

Empirical support for the suggestion that more attention is given to large cities is also available. For example, Sharkansky's (1975) analysis of state and federal aid to cities revealed that states were giving almost three times as much aid to cities of over 500,000 than was the federal government. And "the states are giving the greatest aid to the largest cities, and are increasing most the aid to those cities. From 1964-65 to 1972-73 state aid per capita to cities over 500,000 population increased by 270 percent, while per capita aid to other cities increased by 211 percent" (p. 92).

In summary, three issues appear to be important to understanding the relationship between state aid and city need. First, one would do well to analyze state-level as well as city-level variables in seeking to explain state aid responsiveness to urban needs. This approach was used by Morgan and England (forthcoming). Second, one's choice of sample should consider groups of cities with more severe problems that might be expected to evoke some state response. But the most critical factor to address is the proper way to measure state intergovernmental aid to cities. The analysis described below concentrates on the residual portion of state aid which is unrelated to city population size. Thus, this study looks beyond the fair-share allocation to the part of state aid that may be determined by consideration of differential needs in cities. 


\section{Research Design}

The analysis that follows is an examination of residual state aid to cities. The hypothesis is that residual state aid expenditures to cities are largely determined by city needs. The research question addressed is: how responsive is residual state aid to city needs? More specifically, how important are measures of city need in the determination of residual state aid monies? The second question to be examined is: what aspects of city need are most strongly linked to residual state aid received? The final issue to be addressed is: has the importance of city needs in determining residual state aid changed over time?

\section{Sample}

The units of analysis in this study are cities - the forty-seven largest U.S. cities with 1970 populations of at least 300,000 (see Appendix). ${ }^{3}$ This group of large cities is similar to samples used in several analyses mentioned above, particularly those of Nathan and Adams (1976) and Cuciti (1978). Such a sample gives attention to cities with empirically documented distress and to the major urban population and problem centers in states.

The analysis takes place for two time periods -1962 and 1976. The first point was chosen because, although problems were beginning to develop in cities at this time, the importance of the problems had not yet caused policymakers in state capitals-but more particularly in Washington - to begin funneling massive aid monies to cities. Also, the early 1960 s was a period when states were considered to be the "weak sister" in the intergovernmental picture (Martin, 1965, p. 77; Sundquist, 1969, pp. 261-66). The choice of 1962 as the first point of analysis is purposely intended to reflect the condition of state aid to cities at a time when states were not thought to be attuned to urban affairs. The second time point, fifteen years later, was selected to allow for an examination of the states' responses to the urban crisis. A basic assumption here is that a significant change would have taken place from that observed in 1962. This change is one that could be attributable to the heightened emphasis on the urban crisis.

\section{Measures of State Aid}

The dependent variables include total intergovernmental revenue from state government received by the sample cities in 1962 and $1976 . .^{4}$ As

\footnotetext{
${ }^{3}$ Washington, D.C. is not included among the largest cities because it is not a political subdivision of a state.

${ }^{4}$ The revenue data are drawn from U.S. Bureau of the Census, City Goternment
} 
reported by the Census Bureau, this measure includes state grants-in-aid, state-city revenue sharing, reimbursements, and payments in lieu of taxes. The state aid data also include federal pass-through aid. Most of the pass-through money goes to support local education and welfare programs. ${ }^{5}$ Few cities included in the sample receive large amounts of federal pass-through funds because school districts or county governments are generally the recipients of school and welfare money, respectively. A small number of cities in this sample do receive large amounts of education and welfare pass-through funds (e.g., New York). The inclusion of data on these few cities is not expected to be problematic in the analysis that follows.

Accepting the arguments of Uslaner (1976) and Ward (1981) on the use of per capita measures, regression is employed here to produce residuals of state aid. Preliminary analysis of the data in this study showed a simple correlation between total state aid received and city population of .90 in 1962 and .88 in 1976. (Both correlations were significant below .001.) These correlations suggest that 81 percent of state aid received in 1962 and 77 percent of that in 1976 could be explained by city population alone. As previously addressed, the alternative to per capita methods for achieving a population adjustment is made possible with regression. This will allow the researcher to focus on the 19-23 percent of state aid that is determined by factors other than population. To produce residual measures the 1962 state aid data were regressed on the 1960 city population, while the 1976 data were similarly regressed on the 1975 population. The resulting residuals are then employed as the dependent variables in this study. The residuals for both years were found to meet the test of independence through a correlation of each with population. The simple correlation between residual aid and population was -.008 for 1962 and -.009 for 1976 .

\section{Measures of City Need}

Following previous research, the conceptual use of need in this study follows the notion of three dimensions: social need, economic need, and fiscal need. Social needs are the problems of people in the city. The dimension includes problems related to poverty, crime, dependency (e.g., elderly), and so forth. The economic health of an area, or the second

Finances in 1962 (Washington, D.C.: Government Printing Office, 1963), table 7; and City Government Finances in 1975-76 (Washington, D.C.: Government Printing Office, 1977), table 7 .

${ }^{5}$ For example, in 1976-77 the total federal pass-through money to local governments was $\$ 12.3$ billion. Out of this total $\$ 10.1$ billion, or 82.1 percent, went to support local education and welfare. 
dimension, considers such conditions as home ownership, density of the city population, and business health indicators. The fiscal need dimension taps the financial health or stress of city governments. This factor includes such items as deficit spending and city service responsibilities.

Several indicators have been chosen for each need dimension. Because of the relative importance of the needs of people, more measures of the social dimension have been included. Just as the choice of using total or per capita measures has been an issue, so too has the form of the independent variables (Ward, 1981). Initially, the decision was made to employ the actual size of the population in need, rather than using the percentage of it. However, as would be expected, population-related measures of social need were found to be strongly associated with city population. To achieve indicators of social need which would not be tied to population, the social need measures were all regressed on population (for the appropriate year). The residuals generated are measures of social need which are linearly adjusted for population. The indicators of social need include: (1) nonwhite residual (minority population 1960, 1970); (2) elderly residual $(1960,1970)$; (3) poverty residual $(1960,1969)$; (4) mobility residual (population moving in previous five years, 1960, 1970); (5) unemployment residual (1962, 1976); and (6) crime residual (serious crimes reported 1960,1975$)$. All of the social need measures are hypothesized to be positively related to residual state aid. Two measures were chosen for the economic need dimension: (1) density (population per square mile 1960,1975$)$, expected to be positively associated with aid; and (2) home ownership (total owner-occupied housing 1960, 1970), anticipated to be negatively related to aid. Finally, the fiscal need dimension is represented by four indicators of the financial health and stress of city governments: (1) budget deficit (general fund deficit spending total, 1962, 1976); (2) debt burden (total general debt as a proportion of general revenue in 1962, 1976); (3) fiscal effort (general revenue/personal income, 1962, 1976); and (4) functional inclusiveness (city responsibility for education and/or welfare services, 1962,1976$).^{6}$ All of the fiscal need indicators should show positive associations with residual state aid.

\section{ANALYSIS}

Table 1 reports the bivariate correlations between the three types of need measures and state aid in 1962 and 1976. Two social need indicators were strongly related to residual state aid in 1962 - nonwhite

\footnotetext{
${ }^{B}$ Similar to that suggested by Liebert (1974), the functional inclusiveness indicator is a measure of the functional responsibilities of city governments. It is coded as follows: $0-$ no city welfare or education responsibility; 1-either responsibility; and 2-responsibility for both functions. This is a measure of city spending responsibility for these two services.
} 
$(-.50)$ and mobility $(-.72)$. Although the negative correlations appear to suggest that higher state aid payments were observed in cities with lesser social needs, the signs lack substantive interpretation in analyzing residual social needs and residual state aid. The signs changed as a result of the residualization process that produced the new variables and are statistical artifacts of the procedure. ${ }^{7}$ Residual aid was positively correlated with three other measures of social need-elderly, poverty, and crime-but none was significant in 1962. Neither of the economic need

TABLE 1

Bivariate Correlations between Residual Intergovernmental Aid from State Government and City Need Indicators

\begin{tabular}{|c|c|c|}
\hline \multirow[b]{2}{*}{ Indicatons of NeED } & \multicolumn{2}{|c|}{ YEAR } \\
\hline & 1962 & 1976 \\
\hline \multicolumn{3}{|l|}{ Social Need } \\
\hline Nonwhite Residual & $-.50^{*}$ & $-.33^{*}$ \\
\hline Elderly Residual & .24 & $.56^{*}$ \\
\hline Poverty Residual & .23 & $.33^{*}$ \\
\hline Mobility Residual & $-.72^{*}$ & $-.68^{*}$ \\
\hline Crime Residual & .24 & .10 \\
\hline Unemployment Residual & -. & $-.32^{*}$ \\
\hline \multicolumn{3}{|l|}{ Economic Need } \\
\hline Density & .07 & .12 \\
\hline Home Ownership & -.18 & $-.28^{*}$ \\
\hline \multicolumn{3}{|l|}{ Fiscal Need } \\
\hline Budget Deficit & -- & -. \\
\hline Debt Burden & .07 & .18 \\
\hline Fiscal Effort & $.37^{*}$ & $.45^{*}$ \\
\hline Functional Inclusiveness & $.54^{*}$ & $.43^{*}$ \\
\hline 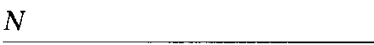 & 44 & 47 \\
\hline
\end{tabular}

Sources: U.S. Bureau of the Census, County and City Data Book, 1962, 1972, 1977 editions; City Government Finances, 1962 and 1975-76 editions; Federal Bureau of Investigation, Crime in the U.S., 1962 and 1975 editions.

${ }^{*} p \leq .05$.

${ }^{7}$ For additional explanation, note that both the dependent variable, state aid, and the independent variables representing social needs (i.e., nonwhite and mobility) are residual variables not "totals" or the size of the social indicator. The original variables, when correlated, displayed positive correlations with one another. In other words, total state aid and the size of the nonwhite (or mobile) population were positively correlated with one another. But in several analyses the residual variables for aid and social need showed negative correlations. There is no substantive or theoretical explanation for this observation. The changes in sign are statistical artifacts of the residuals procedure in regression analysis. For this reason, the direction of the relationship between social need variables and the dependent variable is not discussed in the paper. 
variables correlated highly with aid in this year. But two of the four fiscal need measures did correlate in a moderately strong, positive fashion. Functional inclusiveness had the second strongest correlation among all need measures (.54), while fiscal effort showed a somewhat smaller (.37), although still significant association.

Some support is found in table 1 for the hypothesis that city needs should have been more strongly related to residual state aid in 1976 than in 1962 . By 1976 many states had reformed their government structures to improve their capacity to respond to city problems. In addition, the urban crisis that was going unnoticed in national and state legislative circles in 1962 was well beyond the point of discovery by 1976 . This fact lends support to the presumption that a change in state aid to cities should be noticeable in the second time period. There were five significant correlations between residual state aid and social need indicators in 1976 . Mobility $(-.68)$ and nonwhite $(-.33)$ were again significant, although the strength of the relationships had dropped slightly from the 1962 observations. The three social need indicators that increased in the level of association by 1976 were elderly (.56), poverty (.33), and unemployment $(-.32)$. One economic need variable was found to be significantly related to residual aid in 1976: home ownership $(-.28)$. This was also an increase in the level of association from that observed in 1962. Finally, the same two fiscal need measures were found to be correlated in a moderately strong way with 1976 residual aid. While the measure of fiscal effort increased in strength (.45) in the latter period, the functional inclusiveness indicator was down slightly (.43) from 1962 . Overall, though, more measures of need were found to be associated with residual state aid in 1976 than in the first year studied.

\section{State Aid to Cities in 1962}

Not all variables contained in table 1 could be used in the multivariate analysis that follows. First, there was a multicollinearity problem between two of the fiscal need indicators: fiscal effort and functional inclusiveness in 1962 correlated at .88 . Second, some of the independent variables displayed virtually no association with the dependent measure of residual state aid in table 1 . To ascertain the actual level of importance of each of the independent variables in the determination of residual state aid, a stepwise multiple regression procedure was employed. The following tables display only those variables that made a significant contribution to explained variance in this analysis. The independent variables are ordered according to the step in which they were added to the equation.

As can be seen in table 2, mobility was the most important predictor of 
TABLE 2

\section{Multiple Regression Analysis of City Residual InTERgovernmental Revenue From State Government By NeEd V ARIABles, 1962}

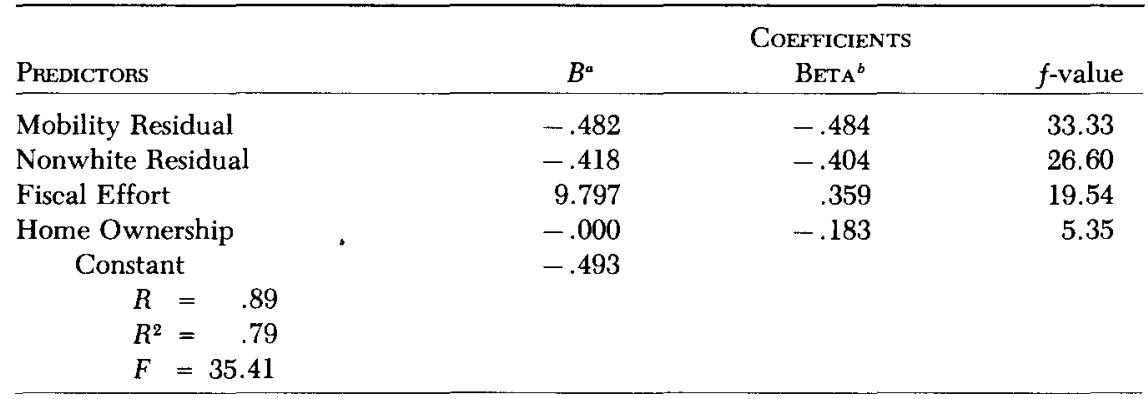

a Unstandardized regression coefficient.

${ }^{b}$ Standardized regression coefficient (beta weight).

residual state aid (Beta $=-.484)$. The second most important predictor, nonwhite, was also a social need indicator and had a similarly high standardized regression coefficient (Beta $=-.404$ ). These two predictors were followed in step 3 of the analysis by fiscal effort (Beta $=.359$ ). Cities making better fiscal efforts appear to have increased their residual state aid by much more than cities with lower fiscal effort $(b=9.797)$. Finally, home ownership was the last variable to enter the equation with a significant regression coefficient (Beta $=-.183$ ). This combination c. social, economic, and fiscal predictors resulted in a significantly high multiple correlation coefficient of .89 and an exceptionally high explained variance of 79 percent. It is significant that fully 79 percent of the variation in residual state aid receipts among these cities was explained by these measures of city need.

To see if the results would differ when fiscal effort was replaced with the functional inclusiveness measure, the latter variable was used as a predictor in a subsequent analysis. The results, shown in table 3 , indicate that once again mobility and nonwhite are the more important predictors of residual state aid. The functional responsibility measure of city education and/or welfare responsibilities entered the equation third (Beta $=.373$ ), as did the fiscal effort variable in table 2 . Although home ownership dropped out of this equation due to a lack of statistical significance, the two social need variables plus the fiscal need predictor do nearly as well as the four predictors in table 2 . The multiple correlation coefficient in this latter analysis is still very high (.88), and the three variables explain 78 percent of the variability in residual state aid receipts in the sample cities. Overall, the results of the 1962 analysis indicate that 


\section{TABLE 3}

Multiple Regression Analysis of City Residual Intergovernmental. Revenue from State Government by Social Need Residuals and Functional InClusiveness, 1962

\begin{tabular}{lccc}
\hline & \multicolumn{3}{c}{ CoEfficients } \\
Prenictors & $B^{\alpha}$ & BETA $^{b}$ & $f$-value \\
\hline Mobility Residual & -.543 & -.544 & 47.51 \\
Nonwhite Residual & -.373 & -.374 & 24.17 \\
Functional Inclusiveness & .551 & .373 & 23.23 \\
$\quad$ Constant & -.209 & & \\
$R=.88$ & & & \\
$R^{2}=.78$ & & & \\
$F=46.74$ & & & \\
\hline
\end{tabular}

${ }^{a}$ Unstandardized regression coefficient.

${ }^{b}$ Standardized regression coefficient (beta weight).

needs were very important in the determination of residual state aid in this year. In fact, the need measures account for all but about 20 percent of the variability in residual state aid in $1962-$ a rather small proportion of unexplained variance.

\section{State Aid to Cities in 1976}

The same stepwise process was used in the analysis of 1976 residual state aid. The intercollinearity between fiscal effort and functional inclusiveness was again high in this period $(r=.80)$. The analysis was tried with each of the fiscal need measures employed in separate analyses, but the resultant coefficients were so similar that only one of these products is displayed below. In table 4 the social need variables are, again, found to be the stronger determinants of residual state aid. Mobility was the strongest predictor (Beta $=-.705$ ) and entered in the first step. Nonwhite entered on step 2, followed by fiscal effort in the third step. Crime, a social need measure, and density, an indicator of economic need, followed into the equation in that order. This combination of three social, one fiscal, and one economic need predictors achieved a significantly high multiple correlation coefficient (.95) and accounted for fully 90 percent of the variation in residual state aid.

It is interesting to observe that only 10 percent of variation in residual state aid for 1976 is not determined by the three dimensions of need. This suggests that only a very small amount of residual state aid is determined by factors not related to city conditions. Another noteworthy finding is the greater importance of needs in this equation than in those analyzed for 1962. Much more of the variation is explained by needs in the latter period - after the urban crisis had been "discovered" and states had ini- 
tiated reforms in their governmental structures to accommodate urban concerns - than in the pre-urban crisis period. This finding lends support to the assumption made earlier that residual state aid would be more responsive to measures of city need in 1976.

\section{TABLE 4}

Multiple Regression Analysis for City Residual INTERGOVERNMENTAL REVENUE FROM STATE Government by NeEd Variables, 1976

\begin{tabular}{|c|c|c|c|}
\hline \multirow[b]{2}{*}{ Predictors } & \multicolumn{3}{|c|}{ CoffFicients } \\
\hline & $B^{a}$ & BETA $^{b}$ & $f$-value \\
\hline Mobility Residual & -.711 & -.705 & 140.21 \\
\hline Nonwhite Residual & -.484 & -.462 & 71.40 \\
\hline Fiscal Effort & 7.035 & .564 & 49.52 \\
\hline Crime Residual & 1.042 & .257 & 21.55 \\
\hline Density & -.000 & -.400 & 26.33 \\
\hline Constant & -.123 & & \\
\hline$R=$ & & & \\
\hline$R^{2}=.90$ & & & \\
\hline$F=63.80$ & & & \\
\hline
\end{tabular}

a Unstandardized regression coefficient.

${ }^{b}$ Standardized regression coefficient (beta weight).

\section{Discussion}

This study began with the basic hypothesis that residual state aid is largely determined by city needs. The hypothesis was examined in relation to three research questions. First, how responsive is residual state aid to city needs? The evidence from this research suggests that such aid is very responsive to some common indicators of city need. A combination of social and fiscal need measures explained nearly 80 percent of residual state aid receipts in 1962 . A similar group of social, economic, and fiscal need measures accounted for 90 percent of aid variation in 1976. One may reasonably conclude from these findings that state aid programs have been responsive to city needs throughout the period.

A second question deals with the relative impact of the three need dimensions in explaining residual state aid. It seems safe to conclude that the social need dimension was the most important aspect of need among the three factors examined. At least two social need predictors were found to be salient in each equation, and in all cases the social need measures were the strongest predictors of residual state aid during the years examined. Fiscal need predictors seem to have less but still significant importance, especially in light of the contributions of both fiscal effort and functional inclusiveness in 1962 and 1976. The economic need 
dimension was found to be the weakest in all equations. This may be due to the fewer number of indicators employed in the analysis compared with the other dimensions. Since the social need indicators tap the needsof-people concept, and since the best representation of Tobin's (1979) notion of problems centered in the city may be social needs, it is perhaps fitting that states should be more responsive to this dimension.

The final question focuses on the possible changes in the importance of needs over time. Needs were clearly important in the 1962 residual state aid receipts. This observation is somewhat surprising since states were not thought to be very responsive to urban concerns in the early 1960s. During this period, the federal government was just beginning to create large assistance programs for cities. States were still seen as the weak sister in the intergovernmental picture, and cities very frequently turned to Washington for help with problems. But despite the historical facts, states apparently did a fairly decent job of considering needs in the residual aid examined here. By 1976, state governments were even more responsive to city needs as measured by the larger explained variation in that year's analysis. This may have resulted from improved state government structures (including many recently established departments of Community or Urban Affairs), increased representation of urban areas following reapportionment, and heightened awareness in state capitals of the plight of large cities.

The results of this analysis are the strongest findings yet in support of the positive role played by the states in helping city governments. The findings lend support to the works of Dye and Hurley (1978), the National Governors' Association (1979), and Stein (1981b, 1982), which suggest that states have been responsive to city needs.

While this research has looked at only one aspect of state responsiveness - targeting aid to urban needs - the findings have policy implications for cities. As addressed earlier, Reagan's New Federalism proposals have been a source of concern to city governments that have not viewed state government to be a good targeter of aid. The new administrative mechanisms of New Federalism, along with smaller federal outlays, give targeting additional meaning. State targeting will be very important to needy cities that may get larger outlays. But at the same time, smaller and less needy cities may suffer with smaller outlays due to state targeting. All this considered, if the findings reported here for 1962 and 1976 continue into the 1980s, then cities may enjoy a sense of optimism (if the resources are available) about state responsiveness to their problems. 


\section{REFERENCES}

Advisory Commission on Intergovernmental Relations (1981a). The Future of Federalism in the 1980s. Washington, D.C.: U.S. Government Printing Office. (1981b). "State Efforts to Prevent and Control Local Financial Emergencies." Information Bulletin 81-82 (September): 1-26.

(1981c). State-Local Relations Bodies: State ACIRs and Other Approaches. Washington, D.C.: U.S. Government Printing Office.

Bunce, Harold (1976). An Evaluation of the Community Development Block Grant Formula. Washington, D.C.: U.S. Department of Housing and Urban Development.

Carmines, Edward (1974). "The Mediating Influence of State Legislatures on the Linkage Between Interparty Competition and Welfare Policies." American Political Science Review 68: 1118-24.

Cnudde, Charles, and Donald J. McCrone (1969). "Party Competition and Welfare Policies in the American States." American Political Science Review 63: 858-66.

Cohen, Neal M. (1982). "Community Assistance: The States' Challenge." Intergovernmental Perspective 8: 14-21.

Cortes, Fernando, and Adam Przeworski (1971). "Per Capita or Sin Capita: A Note of Caution." Paper presented at Annual Meeting of the American Political Science Association, Chicago.

Cuciti, Peggy (1978). City Need and the Responsiveness of Federal Grant Programs. Report to the U.S. House of Representatives, Committee on Banking, Finance, and Urban Affairs, Subcommittee on the City, 95th Congress, 2d Session. Washington, D.C.: U.S. Government Printing Office.

Dearborn, Philip H. (1977). Elements of Municipal Financial Analysis, Part II: Budget Performance. Boston: First Boston Corporation.

Dye, Thomas R., and Thomas L. Hurley (1978). "The Responsiveness of Federal and State Governments to Urban Problems." Journal of Politics 40: 196-207.

Gorham, William, and Nathan Glazer, eds. (1976). The Urban Predicament. Washington, D.C.: The Urban Institute.

Gray, Virginia (1973). "Innovation in the States: A Diffusion Study." American Political Science Review 67: 1174-88.

Grumm, John G. (1971). "The Effects of Legislative Structure on Legislative Performance." In Richard I. Hofferbert and Ira Sharkansky (eds.), States and Urban Politics. Boston: Little, Brown.

Kmenta, Jan (1971). Elements of Econometrics. New York: The Macmillan Co.

Lawson, Jean, and Carl W. Stenberg (1982). “'Rebalanced Federalism': The States' Role and Response." Intergovernmental Perspective 8: 30-41.

Liebert, Roland J. (1974). "Municipal Functions, Structure and Expenditures: A Reanalysis of Recent Research.” Social Science Quarterly 54: 765-83.

Martin, Roscoe C. (1965). The Cities and the Federal System. New York: Atherton.

Morgan, David R., and Robert E. England (forthcoming). "State Aid to Cities: A Causal Inquiry." Publius.

Nathan, Richard P., and Charles Adams (1976). "Understanding Central City Hardship." Political Science Quarterly 91: 47-62.

National Governors' Association (1979). Bypassing the States: Wrong Turn for Urban Aid. Washington, D.C.: National Governor' Association, Center for Policy Research.

Netzer, Dick (1970). "Financing Urban Government." In James Q. Wilson (ed.), The Metropolitan Enigma. Garden City, NY: Anchor Books/Doubleday and Co.

Peterson, George E. (1976). "Finance." In William Gorham and Nathan Glazer (eds.), The Urban Predicament. Washington, D.C.: The Urban Institute. 
Saltzstein, Alan L. (1977). "Federal Categorical Aid to Cities: Who Needs It Versus Who Wants It." Western Political Quarterly 30: 377-83.

Savage, Robert L. (1978). "Policy Innovativeness as a Trait of American States." Journal of Politics 40: 212-24.

Schmid, Gregory, Hubert Lipinsky, and Michael Palmer (1975). An Alternative Approach to General Revenue Sharing: A Needs Based Allocation Formula. Washington, D.C.: Institute for the Future.

Sharkansky, Ira (1975). The United States: A Study of a Developing Country. New York: David McKay Company.

Sharkansky, Ira, and Richard I. Hofferbert (1969). "Dimensions of State Politics, Economics and Public Policy." American Political Science Review 63: 867-79.

Stein, Robert M. (1981a). "The Allocation of Federal Aid Monies: The Synthesis of DemandSide and Supply-Side Explanations." American Political Science Review 75: 334-43.

(1981b). "The Targeting of State Aid: A Comparison of Grant Delivery Systems." The Urban Interest 3 (Special Issue): 47-59.

(1982). "The Allocation of State Aid to Local Governments: An Examination of Interstate Variations." In Advisory Commission on Intergovernmental Relations, State and Local Roles in the Federal System. Washington, D.C.: Government Printing Office.

Stephens, G. Ross (1974). "State Centralization and the Erosion of Local Autonomy." Journal of Politics 36: 44-76.

Stephens, G. Ross, and Gerald W. Olson (1979). Pass-Through Federal Aid and Interlevel Finance in the American Federal System, 1957 to 1977. Vol. 1. A Report to the National Science Foundation. Kansas City: University of Missouri.

Sundquist, James L., with David W. Davis (1969), Making Federalism Work: A Study of Program Coordination at the Community Level. Washington, D.C.: Brookings Institute.

Teitelbaum, Fred, David D. Arnold, and Dorrett Lyttle (1981). "State Assistance to Distressed Cities." The Urban Interest 3 (Special Issue): 60-72.

Tobin, Gary A., ed. (1979). The Changing Structure of the City. Beverly Hills, CA: Sage Publications.

Tompkins, Gary L. (1975). "A Causal Model of State Welfare Expenditures." Journal of Politics 37: 392-416.

Uslaner, Eric M. (1976). “The Pitfalls of Per Capita." American Journal of Political Science 20: 125-33.

Walker, Jack L. (1969). "The Diffusion of Innovations Among the American States." American Political Science Review 63: 880-99.

Ward, Peter D. (1981). "The Measurement of Federal and State Responsiveness to Urban Problems." Journal of Politics 43: 83-101.

Wonnacott, Ronald J., and Thomas H. Wonnacott (1970). Econometrics. New York: John Wiley and Sons. 


\section{APPENDix}

Sample Cities and Residuals for State Aid, 1962, $1976(N=47)$

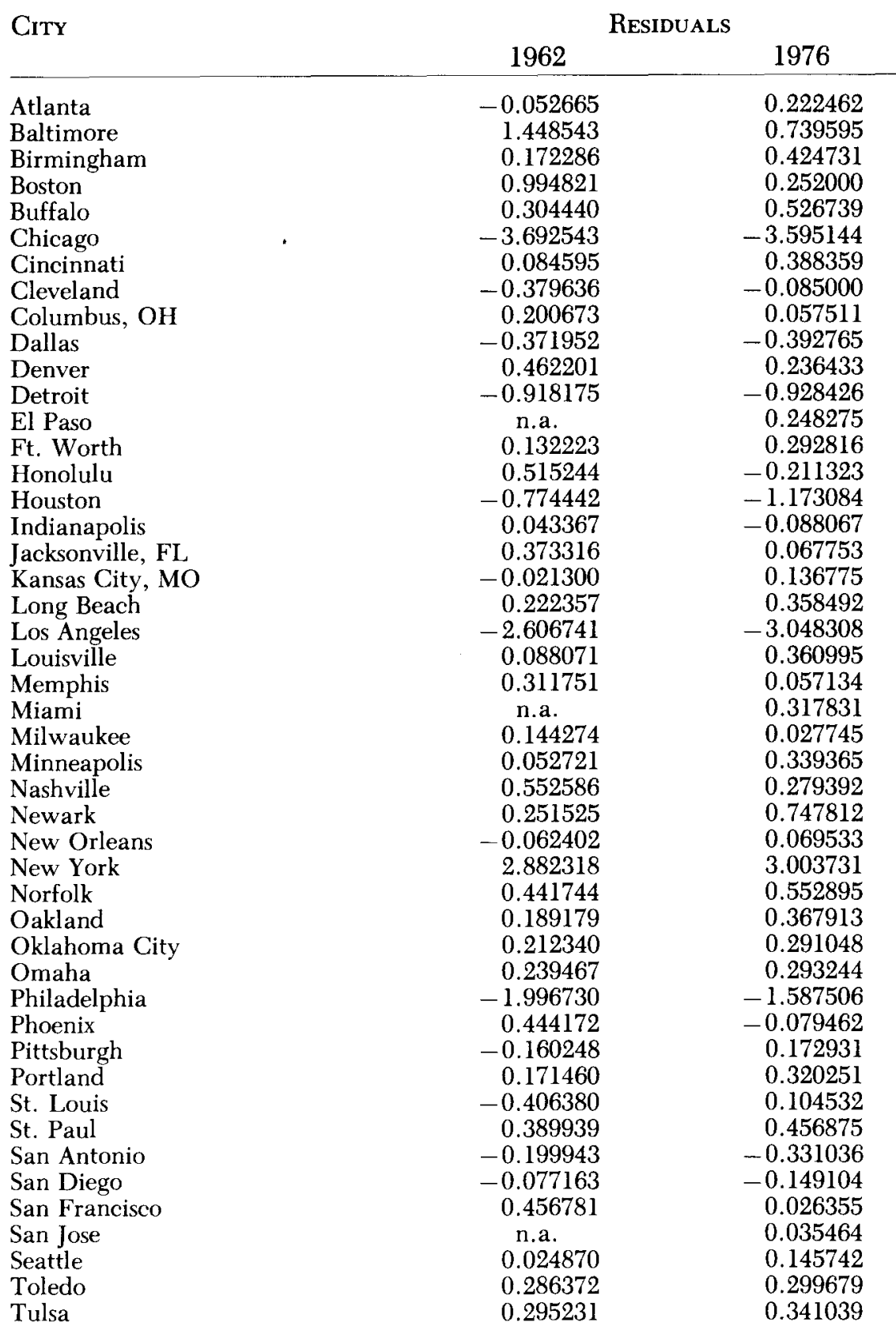

